\title{
Reimagining Numeracies: Empowered, Game-Informed Meaning Making in and beyond the Pandemic Era
}

\author{
SANDRA SCHAMROTH ABRAMS \\ St. John's University
}

\begin{abstract}
This article focuses on how a game-informed culture in public school math classes sustained interaction, cooperation, and empowered meaning making when COVID-19 mandates closed school buildings and education went fully online. More specifically, the game-informed learning environment supported the students' development and discussion of their multimodal numeracies, and the highlighted activity reveals how the generation of math memes can foster students' engagement in creative and empowered practices. Underscored throughout this article is the importance to embrace the expansiveness of numeracies in order to recognize, value, and support students' meaning making.
\end{abstract}

\section{Keywords}

coopertition, game-informed, math memes, numeracies

\section{Introduction}

In March 2020, following gubernatorial executive orders, schools in the Tri-State Area (New York, New Jersey, and Connecticut) suspended all in-person instruction due to the COVID-19 pandemic. Early reports of educational responses to this dramatic and sweeping shift noted that, across the United States, the number of students online grew exponentially from 1 million to 55 million (Butcher, 2020; Schaefer et al., 2020, 2021; Turner et al., 2020) and the resulting "pandemic pedagogy" (Milman, 2020, ๆ5) included K-12 educational triage; teachers, administrators, and parents all were trying to find a way to educate students in light of constraints that ranged from emotional and physical wellbeing to access to and proficiency with digital resources (Schaefer et al., 2020). Although many of these initial issues persist, this article offers a vista into a class culture and an activity that supported students' numeracies, creativity, and empowerment despite uncertain and disempowering circumstances.

This article focuses on one activity - the generation of math memes - in two public school Algebra classes that, prior to the COVID-19 pandemic, had adopted a gameinformed ethos (Abrams, 2021, in press; Begg, 2008; Begg et al., 2005), which emphasizes cooperative meaning making in and around games and game-related practices. The culture of the class, therefore, included the type of cooperative ideation and support that helped to sustain engagement and interaction in the Zoom breakout rooms ${ }^{1}$ during the stay-at-home

\footnotetext{
${ }^{1}$ Zoom is a videoconference platform that includes breakout rooms, or individual videoconference spaces that branch off - but remain relatively tethered to - the main videoconference session (i.e., the host of the overall Zoom session manages the creation and duration of the breakout rooms; however, one can exit the breakout room at any time either to go back to the main room or to leave the entire session). Often breakout rooms are used to facilitate group conversations or collaborative work.
}

\begin{tabular}{lll}
\hline \hline Language and Literacy & Volume 23, Issue 2, 2021 & Page 16
\end{tabular}


order. To situate this study, in what follows is an explanation of the classroom culture and game-informed learning, as well as a discussion of numeracies and memes. Thereafter, students' memes are discussed in light of their numeracies, and suggestions for future research and practice are addressed.

\section{Going Remote}

Beginning in 2014 and continuing through present day, I have been engaged in participatory research in a public high school located approximately 30 miles from New York City. From mid-March through mid-June, 2020, I had the privilege to extend my ongoing brick-and-mortar school partnership into the Zoom videoconference space with a teacher and his students. Initially, with the sudden move online, my role was that of volunteer assistant and facilitator. With an IRB amended specifically in light of COVID19 to include videoconference and related spaces, my "complete role" as a "co-participant personally immersed in the social world studied" (Saldaña \& Omasta, 2018, p. 36; Adler $\&$ Adler, 1987) meant being on Zoom with my camera and microphone turned on $^{2}$ and interacting with students and the teachers ${ }^{3}$ using voice and chat ${ }^{4}$ communication.

In these roles, throughout the 14 weeks we were on Zoom, I provided support to Mr. G. and to his students (all names and identifiers are obscured by pseudonyms). This included, but was not limited to, helping Mr. G. and the students acclimate to Zoom; helping to develop and facilitate instructional activities and breakout rooms; admitting students into the Zoom room from the virtual waiting room while Mr. G. was teaching ${ }^{5}$; offering clarifications via chat when students did not hear instructions; signaling to Mr. G. when students had a question and he did not (or could not) see them; and suggesting Mr. G. adjust his laptop to change the angle of the screen-based camera so that students could see his work. Although Mr. G. occasionally used the screen share option (i.e., enabling students to see a particular document or program on his computer), he typically focused the laptop's built-in camera on a dry erase whiteboard upon which he wrote math problems to help students work through steps of an equation.

Although this article draws upon data from a larger, now seven-year study, the specific data reported are related to a particular meme activity that students completed in May 2020. However, given my ongoing research in the public high school and my presence in the brick-and-mortar classroom prior to the stay-at-home orders, students were accustomed to my presence, and I had developed a rapport with students that then carried over into the Zoom main room and breakout rooms. Students' familiarity with, and acknowledgement of, my presence surfaced in end-of-year feedback Mr. G. and I received, which included comments, such as, "I liked how Doc A was apart [sic] of our class! It was nice of her to come to our school and even staying with us on the zoom calls! I felt that every time she came in she always made me think and look at things from a different/ better

\footnotetext{
${ }^{2}$ On occasion, when background noise in my home was distracting, I muted my microphone to minimize class disruption.

${ }^{3}$ Although there were other teachers online for other classes, this study focuses on two Algebra classes that Mr. G. taught.

${ }^{4}$ Zoom's internal chat feature enabled me to distribute to the class teacher-approved links and instructions.

${ }^{5}$ Sometimes students were late or lost their Internet connection and needed to be admitted to the Zoom room after class had started.
}

\begin{tabular}{lll}
\hline \hline Language and Literacy & Volume 23, Issue 2, 2021 & Page 17
\end{tabular}


light. The math subject projects she introduced were fun to make!" and "Doctor A, I would like to thank you for all the time that you have devoted to our class. The days that you came in were always so much fun and you have never even missed a single zoom call." Such feedback is not included for self-aggrandizement, but, rather, specifically to underscore the breadth and quality of the time I spent with Mr. G. and his students.

\section{A Classroom Culture Informed by Gaming and Numeracies}

For the 2019-2020 academic year, as we had in the past, Mr. G. and I worked closely to develop a classroom culture of respectful interaction vis-à-vis coopertition ${ }^{\circledR}$, a concept coined by the For Inspiration and Recognition of Science and Technology (FIRST) robotics organization (FIRST, 2017). Cooperative competition-or coopertitionemphasizes that winning is not a solitary action. In the act of assisting others, one can still achieve personally while elevating the overall performance of others and the class. A FIRST robotics competition I observed almost a decade ago involved one team manipulating its robot to help another team's robot balance on a seesaw-like platform. What occurred was inspiring: Opponents became partners and both teams simultaneously balanced their robots on the platform, thereby earning points, an achievement that would have been exponentially more difficult as a solitary effort (Abrams, 2015). This type of adhocracy (cf. Jenkins et al., 20096) involves the type of cooperative activity necessary for contemporary workspaces:

This focus on teamwork and collaboration is also, not coincidentally, how the modern workplace is structured - around ad hoc configurations of employees, brought together because their diverse skills and knowledge are needed to confront a specific challenge and then dispersed into different clusters of workers when new needs arise. (Jenkins et al., 2009, pp. 74-75)

Such an approach also helps students to remain aware of others' needs and creates a classroom culture that is community-oriented (Abrams, 2017, 2018).

\section{Game-Informed Meaning Making}

In the math classroom, coopertition has appeared in a number of ways-from creating and/or playing games (Abrams, 2017) to taking cooperative tests (Abrams, 2018, 2021, in press) to experimenting with and building structures (Abrams \& LaRocca, 2020) - wherein students not only have worked together to solve problems cooperatively, but also have engaged in agentive and empowered meaning making, all while invested in helping others. Although some of these activities literally are game-based in that they directly involve the creation or use of a particular game, the ethos of the curricular approach is game-informed (Begg et al., 2005) because the overall focus is not on the "game as a host into which curricular content can be embedded" (Begg et al., 2005, p. 1). Rather, the emphasis is on meaning making that is informed by features of game play, which include, but are not limited to, cooperation, teamwork, problem solving, goal-related challenges, and reflection (Abrams, 2021, in press; Begg, 2008).

Although game-informed learning does not include games per se, it specifically incorporates "lessons learned from game play as a guide to existing educational processes"

\footnotetext{
${ }^{6}$ Jenkins et al. (2009) referenced Cory Doctorow's "Digital utopia and its flaws," a file that is no longer available to investigate as a primary source.
}

\begin{tabular}{lll}
\hline \hline Language and Literacy & Polume 23, Issue 2, 2021 & Page 18
\end{tabular}


(Bronack et al., 2006, p. 220). Game-informed meaning making, therefore, places the focus on the learner, not the game. ${ }^{7}$ Furthermore, in their examination of L2 teaching and learning in nondigital environments not typically associated with gaming, Reinhardt and Sykes (2014) noted that game-informed practices involved "game and play principles as applied in digital and non-digital contexts outside the confines of what one might typically consider a game" (p. 3). The classroom generally has been such a space.

During the 2019-2020 academic year, the game-informed culture of Mr. G.'s classroom included cooperative learning experiences, such as ad hoc group problem solving, riddles, cooperative testing, and the creation of videos to teach others mathematic principles in non-academic, life settings. The culture supported creativity and freedom to explore multiple ways to envision and complete a problem. As 17-year-old Rez noted,

In [Mr. G.]'s class...there is multiple answers to the one problem, that's one thing I enjoy about his class and the projects that you do... And with a lot of [my] other classes, they have a project that's, okay, here's the guidelines. You need to have this by the end of it, and if you don't it's incorrect or it's we need to work on it more. Instead of with [Mr. G.]'s class it's okay here are some of the guidelines-they're pretty loose. But you just need to come up with the final product that makes enough sense for someone to understand it. And that's where I've felt my creativity and freedom just open up. 'Cause I'm not tied down to, okay, here is what the textbook says.

Rez's description of the activities (e.g., "here are some of the guidelines- they're pretty loose") and the class culture (e.g., "where I've felt my creativity and freedom just open up") also resonates with a game-informed ethos. Rez noted that the "super hands-on approach to [math] and...gaming is like other things, there is no one right way to win it. There are multiple ways, and again some people could take ten minutes, some could take two hours." This explanation dovetails with Rez's affinity for activities that are not overtly math-oriented but that apply the concepts learned in class: "creating things where it's still guiding you towards math, but it's not 'okay, this is math." In other words, through the game-informed culture, students had opportunities to understand math in their lives and in and on their own terms.

\section{Numeracies}

Rez's description of the game-informed activities that do not have "one right way" demonstrates how the culture of Mr. G.'s math classroom respected the expansiveness of numeracies. Often, academic numeracy, like academic literacy, privileges school-based learning (Street, 2005) and relates mathematical literacy to aptitude, an ontological stance further supported by the international examination of proficiency, the Programme for International Student Assessment (Abrams, 2021; Meiers \& Trevitt, 2010).

The concept of literacies, which encompasses meaning making beyond alphabetic text to include multiplicitous and multimodal instantiations of meaning (cf. Barton, 1994; Gee, 1989; Street, 1984, 1995) forged an inevitable path for the discussion of numeracies (Baker \& Street, 1996; Baker et al., 2001, 2006; Tomlin et al., 2002). Similar to literacies,

\footnotetext{
${ }^{7}$ Although beyond the scope of this article, game-informed learning also is different from gamification (Deterding et al., 2011; Kapp, 2012) and gameful learning (Deterding et al., 2011; Kalir, 2016), which typically hinge on game-based experiences (cf. Abrams 2021).
}

\begin{tabular}{lll}
\hline \hline Language and Literacy & Volume 23, Issue 2, 2021 & Page 19
\end{tabular}


the concept of numeracies accounts for expansive understandings of mathematical concepts beyond arithmetic to include sociocultural ways numbers and mathematical thinking are applied: "numeracy practices [are] wider than the events in which numerical activity is involved, and so explore the conceptualisations, discourse, values and beliefs and the social relations that surround numeracy events as well as the context in which they are sited (Tomlin et al., 2002, p. 2). Furthermore, Street and Baker (2006) explained that the concept of numeracies - and more specifically multimodal numeracies (e.g., math beyond alphanumeric representations and inclusive of modes, such as gesture, image, performativity) - involve meaning making as a social practice. Such a stance supports an important paradigm shift:

to think of mathematics as a social practice...challenges the top down view of learning associated with such assumptions about secure knowledge - that people simply have to be taught the rules and procedures. Both theoretically and in terms of pedagogy, the social view then, offers a new approach that would start from the rich variety of engagement with mathematical principles evident in people's ordinary lives. (Street \& Baker, 2006, p. 222)

Thus, the concept of numeracies creates an opening for multiple forms of expressing, understanding, and/or applying mathematical principles.

Numeracies also expands the often constrained types of thinking and speaking that occur in traditional school settings, namely correct and single answers (Street, 2005), and it is essential to pay attention to the otherwise "'hidden' features of classroom discourse...important communicative features of classroom interaction that are missed when the focus is on 'correctness', 'definition', formal features of language and 'lack of ambiguity"' (Street, 2005, p. 136). Therefore, game-informed activities, in general, and the meme activity, in particular, helped to invite students' literacies and numeracies into the classroom. Given that "memes can offer students a less formal, but still mathematically meaningful, setting to show their knowledge, where they can take advantage of nonstandard and non-routine abilities, as their creativity, sharpness, and popular culture expertise" (Bini \& Robutti, 2019, p. 1), the activity in Mr. G.'s class not only drew upon students' multimodal communicative practices that typically occurred outside of class, but also offered an image-based approach to thinking about and working through mathematical problems in cooperative and process-oriented ways.

\section{Memes and Meaning}

Contemporary memes might appear to be online, media-based images reconceptualized with captions to convey an idea or a point (Boa Sorte, 2019; Knobel \& Lankshear, 2008), but the concept of the meme is over 40 years old. The meme can be traced to Richard Dawkins (1976/2016), who spoke about the nongenetic, cultural evolution of language in his book, The Selfish Gene. In search of a "noun that conveys the idea of a unit of cultural transmission, or a unit of imitation," Dawkins looked to "“mimeme'...a suitable Greek root," and he abbreviated it to meme because he "want[ed] a monosyllable that sounds a bit like "gene"' (p. 249). Dawkins related memes to genes in that they evolve and pass on in various forms to others. Yet Dawkins also noted that a meme could "alternatively be thought of as being related to 'memory', or to the French word même" (p. 249). Either way, Dawkins dedicated the moniker, meme, to represent any 
cultural thing — “ideas, catchphrases, clothes fashions, ways of making pots or of building arches" (p. 249) - that involve propagation. Citing an informal synthesis by psychologist Nicholas Humphrey, Hawkins explained that "memes should be regarded as living structures, not just metaphorically but technically" (p. 249).

The meme also is understood as a sociocultural construct that involves making, remaking, and remixing (Boa Sorte, 2019; Knobel \& Lankshear, 2007, 2008), and Internet memes "appear to spread and mutate via distributed networks in ways that the original producers cannot determine and control" (Burgess, 2008, p. 101). According to Heylighen (1999), for a meme to be successful, it must be "noticed, understood and accepted by the host" (p. 419), which requires the sender and receiver to have a shared knowledge of the content - be it the image, the caption, or both. In practice, this means that participation includes "using distinctive language, popular-culture references, and certain motifs...[and] participation signals solidarity with the spirit of the phenomenon ('I get it; I'm part of this' or 'I am like you') rather than any particular attention to the information value of these images" (Knobel \& Lankshear, 2008, p. 29). Thus, for a meme to be understood, it needs to have a degree of relatability.

Memes also have been associated with participatory literacies (Burgess, 2008; Knobel \& Lankshear, 2007; Lankshear \& Knobel, 2003) political statements, grief, and contrition (Mielczarek, 2018; Sobande, 2019), as well as activist literacies (Knobel \& Lankshear, 2007; Lankshear \& Knobel, 2003). Reddit has its own section on mathematical memes (Bini et al., 2020), and, although this article focuses on math-related memes, which can be "cultural objects" (Bini et al., 2020, p. 13), they are not to be confused with the memes found on Reddit - "a massive collection of forums where people can share news and content or comment on other people's posts" (Widman, 2020, \1). Literat and van den Berg (2019) called attention to the Reddit-based "MemeEconomy" wherein members assess and value the posted memes. Although an investigation into the creation and evaluation of memes is important, as is deconstructing their form, content, and subversive or persuasive meaning (Boa Sorte, 2019), that practice extends beyond the scope of this article. Likewise, although Bini et al. (2020) noted that the examination of math memes in a classroom takes the memes outside their "natural habitat" online (p. 4), the data presented in this article suggest that student-generated math memes can act as a conduit to students' numeracies in the classroom and can offer insight into how students perceive and apply math in expansive ways.

\section{Memes in Mr. G. 's Classroom: The Study}

The data featured in this article are part of a larger longitudinal study of gaming and meaning making in public high school mathematics classrooms. For this study, observational research of over 130 hours of online classwork complemented hundreds of hours in the classroom prior to COVID-19 remote instruction, and I engaged in three student interviews, one which was a follow-up interview and a member-checking opportunity. Additionally, student artifacts (e.g., their memes), class debriefs, student surveys, formal and informal interviews and planning sessions with Mr. G., researcher field notes, ongoing researcher reflexivity and thick, rich description (Geertz, 1973) enrich and support the integrity of the data and findings (Merriam \& Tisdell, 2016; Saldaña \& Omasta, 2018). 
Data analysis occurred in two formal capacities. First, I engaged in holistic coding vis-à-vis inductive data walking (Abrams, 2017; Eakle, 2007, 2008) wherein the data were reviewed and coded iteratively with highlighted words and passages, as well as bracketed notes and thoughts about emerging themes. Initial codes included, but were not limited to, freedom, life beyond school, values, social connection, reflection, interaction, creativity, and personal meaning, and they were subsumed into two overall themes-empowerment and personal resonance. Then I returned to the memes using Bini et al.'s (2020) framework for identifying the structure and content of a math meme: A "meme base" (or image), the "mathematical idea" (or math concept), and the aspect of being "encoded in a humorous/emotional link" (p. 8). This approach helped me to deconstruct the elements of the meme and consider the larger, often humorous meaning. After all, "capturing the meaning of the meme base and connecting it to the text allows [one] to decode the meme, grasp the joke and laugh" (Bini et al., 2020, p. 8). Given that the game-informed culture is an integrated feature and that this article focuses on students' numeracies, I intentionally weave together the findings of the meme activity and the discussion of students' practices to provide a comprehensive view of the empowered meaning making that took place in the Zoom breakout rooms.

\section{Being Seen, Being Heard}

Throughout our time together on Zoom over the 14 weeks, the students sometimes appeared online in a variety of ways. Some were sitting at a bedroom desk or at a kitchen table; others were lying down or sitting up in their beds; some were lounging on a couch; some had their videos turned off; and others showed the tops of their foreheads or directed the camera to the ceiling. To mitigate sound issues (e.g., audio feedback and background noise), students usually muted their microphones. When the students were not visible, Zoom acted as a one-way mirror in which students could view Mr. G. and his in-home whiteboard, but Mr. G. could not see them: "They're seeing the board; I'm just not seeing them." Mr. G. acknowledged the students' presence even if he could not seem them, and he often relied on humor to do so, saying, "Another ceiling shot. I love ceilings. I'm going to be a ceiling contractor when I get out of here."

The dynamic in the breakout rooms, where most of the coopertition-related activities took place, was different. As one student noted, "I liked the breakout rooms. There would be more talking in the class instead of awkward silence." In the breakout rooms, students more often than not had their videos and microphones turned on. Tenny explained how the math breakout room experiences were unique to his Mr. G.'s math classes: "I loved the breakout rooms...because it is different from all the other classes that use zoom. In math zoom calls we engage in breakout rooms or have discussion where in other zoom calls we just sit there and listen to the teacher talk." Rez echoed this sentiment when he explained that, as also featured in many TikTok videos, there is a common breakout room experience in classes:

it's just silent... and you sit there, you look at your other group mates, then your camera goes off and you're just waiting for the teacher to show up. Everything comes back on, you talk for a few minutes with the teacher, and as soon as they leave you go back to being silent. 
However, perhaps because a culture of communication and game-informed learning supported teamwork throughout the year or perhaps because the activity was engaging, Rez noted that this type of behavior was not part of the meme activity "because that was an activity that was fun."

A classmate offered additional insight, noting that the sociability in cooperative work was missing from the general Zoom space: "I liked going to the breakout room, it gave us some time to get to talk to our classmates, some that we don't talk to or some that we do talk to. But it was a good idea to have this in place so we could work with other people." An important part of coopertition is working with people who are not necessarily part of an immediate friend group and acknowledging them as teammates. Relatedly, other student feedback included: "I saw lots of communication which led to closer friendships," and "I saw support in people helping others out when they needed it." In other words, the students witnessed and experienced empowered meaning making that resonated for them socially, academically, and personally. This article focuses on one particular breakout room activity-making memes - and the ways in which students' numeracies informed their representations of mathematical concepts.

\section{Giving it Meme-ing}

On May 12, 2020, I oversaw and orchestrated the breakout rooms in a rotation- and needs-based ${ }^{8}$ fashion while Mr. G. met with students individually in the main room. This meant that, when Mr. G. asked to meet with a specific student, I used the Zoom features to move that student - in teleport-like fashion-from the breakout room to the main room with Mr. G. In an attempt to smoothen the otherwise swift transition-Mr. G. tried to meet with each of the 20 students $^{9}$ during the 55-minute period-I briefly alerted students when it was their time to meet with Mr. G. Then I "transported" them from their breakout room to their individual session with Mr. G. in the main room. Despite my efforts, there was an abruptness in the breakout room-main room switch, something that I noted as "odd to simply move a student from one space to the next with very little warning" (May 12, 2020 researcher memo).

While Mr. G. met with students individually, the remainder of the class convened in groups in breakout rooms where they engaged in meme-making. Their overall task was to create a meme to convey their understandings of and/or feelings about a mathematical concept. In what follows are two different types of memes. The first attends to the geometric Pythagorean Theorem ${ }^{10}\left(\mathrm{a}^{2}+\mathrm{b}^{2}=\mathrm{c}^{2}\right)$, which often is used to find a missing side of a right triangle. The second meme addresses the mathematical concept and trigonometric mnemonic device, SOH CAH TOA, ${ }^{11}$ which often is used to remember the formula to find missing sides and angles of a right triangle. In their breakout rooms, students used an online meme generator website to find an image (typically a popular meme base) and insert their

\footnotetext{
${ }^{8}$ In breakout rooms, if students needed me, then they pressed the "ask for help" button, and I received a notification telling me that I was needed. Then, with a click of a button, I joined that particular breakout room and addressed the students' concerns or needs.

${ }^{9}$ There were 40 students across both classes.

${ }^{10}$ In the equation, $\mathrm{a}$ and $\mathrm{b}$ represent the sides of the right triangle, and $\mathrm{c}$ represents the hypothenuse.

${ }^{11} \mathrm{SOH}$ : Sine=Opposite/Hypotenuse; $\mathrm{CAH}$ : Cosine=Adjacent/Hypotenuse; TOA: Tangent= Opposite/Adjacent
} 
own captions. In so doing, students completed the cooperative task of creating individual and group memes that represented a math concept and/or their feelings about it; then they submitted these images to Mr. G. and me and later shared them with the class.

In Figure 1, the meme base is the popular singer and songwriter, Drake, using gesture to signal something that is repulsive, juxtaposed to a gesture noting confidence. Using the free meme generator, the students inserted the mathematical problem - a right triangle with an unknown hypotenuse ("c") — to be the target of Drake's disdain, and the Pythagorean Theorem as an accepted, ideal option. When reviewing the meme in a followup interview, Rez immediately explained that the meme is "demonstrating the Pythagorean Theorem, but not in like a relatable way" mostly because "this is not funny; it gets the point across."

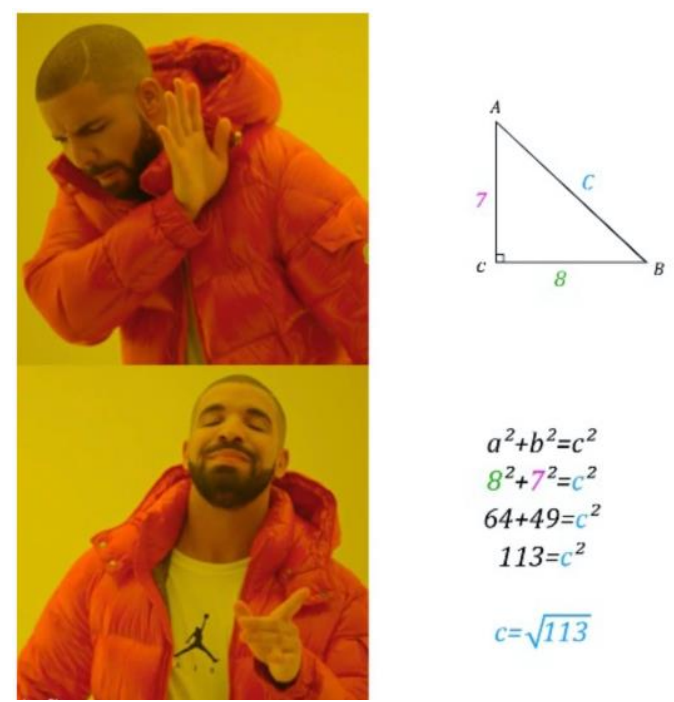

Figure 1. A Meme About the Pythagorean Theorem

Although Rez did not find the Drake meme funny, he noted that the meme activity was "very different from what I'm used to," referring to other math classes in his past that privileged overt, school-related numeracy: "Even when we did projects in previous math classes they were super geared towards math, and your end goal was math." In comparison, Rez perceived the meme activity as an opportunity

to be able to expand that [the end goal], like I know the memes were pretty funny

... here is something that's a little bit more fun, and you're not focused on getting that end result, here is the number you need. It's more of just be yourself, be creative, be funny, and like produce something that makes sense.

In this way, the meme activity enabled students to draw upon other "discourses, values and beliefs and the social relations that surround numeracy events" (Tomlin et al., 2002, p. 2). Furthermore, Rez spoke of overall empowerment and personal relevance, aspects of his numeracies that surfaced through the meme cooperative work.

The creative and humorous side of memes that also resonated for the students appeared to surface in the meme Rez created with his classmates in the Zoom breakout room (see Figure 2). This meme has the Dos Equis ${ }^{\circledR}$ advertisement as the meme base and 
the mnemonic device SOH CAH TOA featured (with an error) as the mathematical idea. What makes this meme comical is that the term SOH CAH TOA is supposed to make it easier for students to remember how to find the sine, cosine, or tangent, but, as Rez explained, his classmates and he did not feel the need to use the acronym because Google was a more effective and efficient form of accessing and understanding math. Perhaps this perspective of memorizing-as-unnecessary is evident in the error SOA (instead of SOH), something Rez acknowledged in the follow-up interview as an oversight: "Oooh! Go us. Honestly. If that doesn't scream COVID brain, I don't know what does.”

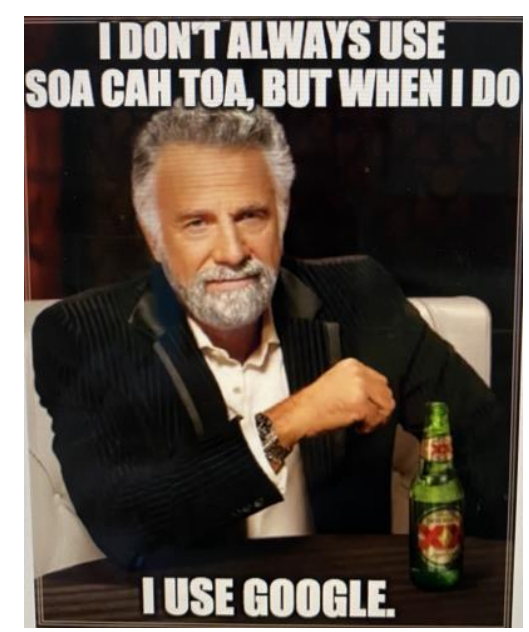

Figure 2. A Meme About Using Google to Understand Math

The message of the meme, however, also is related to a shift in teaching and learning. Unlike the pre-COVID brick-and-mortar classroom in which Mr. G could see student activity and non-phone calculators were the only technology used for tests, remote schooling meant that everyone went online. It comes as no surprise, then, that the sudden use of the Internet supported students' discovery and use of math-related websites. When I asked Rez to explain the meme to me, Rez said, "Well, I remember with the pandemic starting we had a lot more access to the Internet to help guide our learning a little more. And that's where the Google part came from. And this man just seemed to fit the style that we were going for." Rez further explained that Google was a conduit to other sites, such as Wolfram|Alpha and Photomath, that provided detailed answers to mathematical problems. Rez noted, "with the Google aspect of it, we could look up a problem if we had questions on it, and nine times out of ten you'll find the answer."

Rez also spoke of how some of the math apps will "give you a breakdown of exactly how to complete it, and it'll sometimes give you two different ways to do it...it gives you another explanation of it." Although some might view this approach as subversive, what Rez and his groupmates suggested is that their need to memorize certain information is not necessary for them. They can be resourceful, empowered learners who can understand the material another way. This thinking aligns with what neurologist and educator Judy Willis (2012) underscored - that the "model of memorizing facts and procedures was developed to prepare for assembly line work, and it cannot keep up with the information age 
requirements for an educated workforce" (\$12). Although Willis’s words might resonate for Mr. G. and correspond with the game-informed approach in his classroom, the material and format of standardized assessments continue to inform the overall math curriculum.

\section{Game-Informed Numeracies}

The meme activity helped students to express their understandings of math in their own ways, which, by the nature of the activity, hinged on the integration of popular culture. What comes to the fore is how the students saw a connection between their math work and their lives beyond school. As Irie said, "I think the breakout groups were fun and we could do that in real life with memes, etc." Teamwork also was part of the experience: "my favorite was when we would break into teams, have a little assignment and just be in the breakout rooms." Some students saw the elements of gaming in the activities: "I saw all elements this year including fun, support, social interaction, and feedback which i [sic] will remember throughout my high school experience."

Furthermore, the game-informed ethos of the classroom enabled students, like Rez, to envision the relevance of his numeracies in and beyond the school setting. More specifically, Rez spoke about the connections he saw between how he learned in Mr. G.'s class and the skills that he will need in a "practical" work environment:

[With] a lot of math teachers, it's okay, here is the Common Core Standard, ${ }^{12}$ here is how you get this. If you don't do it exactly like this, it is incorrect. And I can't stand that because especially in my industry and what I've taught other people is this is how professionals do it... What does it matter how you got there? If it takes Albert Einstein 10 steps and somehow you get it down to two, go for it. Like if it works and you get the right answer every time so be it.

Rez referred to a business that he helps to run $^{13}$ that primarily involves learning-by-doing, adjusting the angles and positioning of specific equipment, and working with and training others. When describing the mechanics of his work and the various permutations of problem solving he engages in outside school, Rez alluded to his numeracies, which otherwise were hidden (Street, 2005) by traditional approaches beyond Mr. G.'s class.

\section{Reimagining Numeracies: Empowered Meaning Making}

Being able to have that little spark and like ignite it into something bigger is a lot easier to learn from than going all right, here is what you got, here is what you need, just get there. There was a lot more freedom, and I think that promotes a more positive learning environment than here is your equation. (Rez)

Rez's suggestion to embrace discovery and multiple paths to a solution not only is underpinned by mathematical concepts, but also reinforces the importance of freedom to think beyond the test and the "one right way." If education is going to be meaningful for

\footnotetext{
${ }^{12}$ The Common Core Standards were developed in response to international data suggesting "that mathematics education in the United States must become substantially more focused and coherent in order to improve mathematics achievement" (Mathematics Standards, 2021, qI1). However, the implementation and efficacy of the Common Core Standards has been debated (cf. Abrams, 2016; Polikoff, 2017), and there is a lingering question about "convincing causal evidence of the impact of the CCS on any student outcome" (Polikoff, 2017, p. 2).

${ }^{13}$ Given the specificity of the industry, this description protects the identity of the student.
}

\begin{tabular}{lll}
\hline \hline Language and Literacy & Volume 23, Issue 2, 2021 & Page 26
\end{tabular}


students, then from practice to policy, students' numeracies and related practices no longer can be buried by tradition or silenced by academic numeracy and literacy standards.

Furthermore, by embracing the concept of numeracies, educators and education researchers can explore mathematical principles - and students' understandings and applications of them - in ways that not only personally resonate for students, but also help to extend the content area beyond the confines of the online or offline classroom. The meme activity highlighted in this article is but one way to recognize and value students' perceptions and knowledge of mathematical concepts.

Making meaning in and beyond the pandemic era means hearing students' voices and supporting students through cooperative opportunities. One student noted that he "personally would not be where I am unless I had help from other people," an acknowledgement that meaning making is not a solitary act in a solitary space, and a philosophy that is part of coopertition and game-informed learning because interaction with others is key to achievement. The voices of the students and of Mr. G. all advocate for something more, something relevant, something meaningful. A game-informed culture empowers students to bring their meaning(s) to class, and the meme activity provides insight into the layered and textured practices that are part of students' multimodal numeracies. Building upon this model, teachers need to work with students to create a receptive, open, and safe space for individual and cooperative expression, experimentation, and feedback. With freedom and space to learn, students can flourish and, as one student acknowledged, "grow as a person in and out of the classroom."

\section{References}

Abrams, S. S. (2015). Integrating virtual and traditional learning in 6-12 classrooms: A layered literacies approach to multimodal meaning making. Routledge.

Abrams, S. S. (2016). Zombies, boys, and videogames: Problems and possibilities in an assessment culture. In V. Carrington, J. Rowsell, E. Priyadharshini, \& R. Westrup (Eds.), Generation z: Zombies, popular culture, and educating youth (pp. 131142). Springer.

Abrams, S. S. (2017). Cooperative competition, reflective communication, and social awareness in public high school math classes. In Y. Baek (Ed.), Game-based learning: Theory, strategies and performance outcomes (pp. 357-370). Nova.

Abrams, S. S. (2018, April 13-17). Collaborative testing and game-based learning in high school mathematics classes. American Educational Research Association Annual Meeting, New York.

Abrams, S. S., \& LaRocca, T. (2020). Play in the making: Developing a range of literacies through making and game-based activities. In C. McLean \& J. Rowsell (Eds.), Making futures: Maker literacies and maker identities in the digital age (pp. 131-142). Routledge.

Abrams, S. S. (2021). Game-informed meaning making in math class: Cooperative competition and students' literacies/numeracies. [Manuscript submitted for publication]. Department of Curriculum and Instruction, St. John's University.

Abrams, S. S. (in press). Game-informed cooperative assessments and socially 
responsible learning in public school math classes. In M. Harvey \& R. Marlatt (Eds.), Esports research and its integration in education. IGI Global.

Adler, P. A., \& Adler, P. (1987) Membership roles in field research. SAGE.

Baker, D., \& Street, B. V. (1996). Literacy and numeracy models. In A. C. Tuijnman (Ed.), The international encyclopedia of adult education and training (pp. 79-85). Elsevier Science.

Baker, D., Street, B. V., \& Tomlin, A. (2001). Understanding home school relations in numeracy. Proceedings of the British Society for Research into Learning Mathematics, 21(2), 41-48.

Baker, D., Street, B. V., \& Tomlin, A. (2006). Navigating schooled numeracies: Explanations for low achievement, in mathematics of UK children from low SES background. Mathematical Thinking and Learning, 8(3), 287-307. https://doi.org/10.1207/s15327833mt10803_5

Barton, D. (1994). Literacy: An introduction to the ecology of written language. Blackwell.

Begg, M. (2008). Leveraging game-informed healthcare education, Medical Teacher, 30(2), 155-158.

Begg, M., Dewhurst, D. \& Macleod, H. (2005). Game-informed learning: Applying computer game processes to higher education. Innovate, 1(6), 1-7.

Bini, G., \& Robutti, O. (2019). Yo math is so arty: Inspiring creative learning with mathematical internet memes. In S. Goldstine, D. McKenna, \& K. Fenyvesi (Eds.), Proceedings of bridges 2019: Mathematics, art, music, architecture, education, culture (pp. 583-586). Tessellations Publishing. http://archive.bridgesmathart.org/2019/bridges2019-583.pdf

Bini, G., Robutti, O., \& Bikner-Ahsbahs, A. (2020). Maths in the time of social media: Conceptualizing the Internet phenomenon of mathematical memes. International Journal of Mathematical Education in Science and Technology, 1-40. https://doi.org/10.1080/0020739X.2020.1807069

Boa Sorte, P. (2019). Internet memes: Classroom perspectives in the context of digital cultures. Revista Educação \& Formação, 4(12), 51-66.

Bronack, S., Riedl, R., \& Tashner, J. (2006). Learning in the zone: A social constructivist framework for distance education in a 3-dimensional virtual world. Interactive Learning Environments, 14(3), 219-232.

Burgess, J. (2008). 'All your chocolate rain are belong to us'? Viral video, YouTube and the dynamics of participatory culture. In G. Lovink \& S. Niederer (Eds.). Video vortex: Reader response to YouTube (INC Reader \#4, pp. 101-109). Institute of Network Cultures.

Butcher, J. (2020). Public-private virtual-school partnerships and federal flexibility for schools during COVID-19. Mercatus Center. https://nepc.colorado.edu/thinktank/coronavirus

Dawkins, R. (1976/2016). The selfish gene (40 ${ }^{\text {th }}$ anniversary ed.). Oxford Landmark Science.

Deterding, S., Dixon, D., Khaled, R. \& Nacke, L. (2011). From game design elements to 
gamefulness: Defining 'gamification.' MindTrek, Proceedings of the 15th International Academic MindTrek Conference: Envisioning Future Media Environments, 9-15. https://doi.org/10.1145/2181037.2181040

Eakle, A. J. (2007). Literacy spaces of a Christian faith-based school. Reading Research Quarterly, 42(4), 472-510.

Eakle, A. J. (2008). Museum literacy, art, and space study. In J. Flood, S.B. Heath and D. Lapp (Eds.), Handbook of Research on Teaching Literacy Through the Communicative and Visual Arts, (Vol. II, pp. 177-186). Routledge.

FIRST Values. (2017). FIRST Vision and Mission. http://www.firstinspires.org/about/vision-and-mission

Gee, J. P. (1989). Literacy, discourse, and linguistics: Introduction. Journal of Education, 171(1), 5-17.

Geertz, C. (1973). The interpretation of cultures. Basic Books.

Heylighen, F. (1998, August). What makes a meme successful? Selection criteria for cultural evolution. Symposium on memetics: Evolutionary models of information transmission, 15th International Congress on Cybernetics (pp. 413-418), Namur, Belgium. http://cogprints.org/1132/1/MemeticsNamur.html

Jenkins, H., Purushotma, R., Weigel, M., Clinton, K., \& Robison, A. (2009). Confronting the challenges of participatory culture: Media education for the 21[st] century. MIT Press.

Kapp, K. M. (2012). The gamification of learning and instruction: game-based methods and strategies for training and education. John Wiley \& Sons.

Kalir, J. (2016). Conclusion: Good game: On the limitations of puzzles and possibilities for gameful learning. In C. Williams-Pierce (Ed.), Teacher pioneers (pp. 359371). ETC Press.

Knobel, M., \& Lankshear, C. (2007). Online memes, affinities, and cultural production. In M. Knobel \& C. Lankshear (Eds.). A new literacies sampler (pp. 199-227). Peter Lang.

Knobel, M., \& Lankshear, C. (2008). The art and craft of endless hybridization. Journal of Adolescent \& Adult Literacy, 52(1), 22-33.

Lankshear, C., \& Knobel, M. (2003). New literacies. Open University Press.

Literat, I., \& van den Berg, S. (2019). Buy memes low, sell memes high: Vernacular criticism and collective negotiations of value on Reddit's MemeEconomy.

Information, Communication, \& Society, 22(2), 232-249.

https://doi.org/10.1080/1369118X.2017.1366540

Mathematics Standards. (2021). Common Core State Standards Initiative. http://www.corestandards.org/Math/

Meiers, M., \& Trevitt, J. (2010). Language in the mathematics classroom. The Digest, 2010(2), 1-17.

Merriam, S., \& Tisdell, E. J. (2016). Qualitative research: A guide to design and implementation $\left(4^{\text {th }}\right.$ ed.). Jossey-Bass.

Mielczarek, N. (2018). The dead Syrian refugee boy goes viral: Funerary Aylan Kurdi memes as tools of mourning and visual reparation in remix culture. Visual Communication, 19(4), 506-530. https://doi.org/10.1177/1470357218797366

Milman, N. B. (2020, March 30). This is emergency remote teaching, not just online 
teaching. Education Week. https://www.edweek.org/leadership/opinion-this-isemergency-remote-teaching-not-just-online-teaching/2020/03

Polikoff, M. S. (2017). Is common core "working"? And where does common core research go from here? AERA Open, 3(1), 1-6. https://doi.org/10.1177/2332858417691749

Reinhardt, J., \& Sykes, J. M. (2014). Digital game and play activity in L2 teaching and learning. Language Learning \& Technology, 18(2), 2-8.

Saldaña, J., \& Omasta, M. (2018). Qualitative research: Analyzing life. SAGE.

Schaefer, M. B., Abrams, S. S., Kurpis, M., Abrams, M., \& Abrams, C. (2020). "Making the unusual usual": Students' perspectives and experiences of learning at home during the COVID-19 pandemic. Middle Grades Review, 6(2).

Schaefer, M. B., Abrams, S. S., Kurpis, M., Abrams, C., \& Abrams, M. (2021). Pandemic meaning making: Messing toward motet. English Teaching: Practice \& Critique. https://doi.org/10.1108/ETPC-07-2020-0073

Sobande, F. (2019). Memes, digital remix culture and (re)mediating British politics and public life. Progressive Review, 26(2), 151-160. https://doi.org/10.1111/newe.12155

Street, B. V. (1984). Literacy in theory and practice. Cambridge University Press.

Street, B. V. (1995). Social literacies: Critical approaches to literacy in development, ethnography, and education. Longman.

Street, B. V. (2005). The hidden dimensions of mathematical language and literacy. Language and Education, 19(2), 135-140. https://doi.org/10.1080/09500780508668669

Street, B. V. \& Baker, D. (2006). So, what about multimodal numeracies? In K. Pahl and J. Rowsell (Eds.), Travel notes from the New Literacy Studies: Instances of practice (pp. 219-233). Cromwell Press.

Tomlin, A., Baker, D., \& Street, B. (2002). Home and school numeracy practices: Where are the borders and overlaps. In P. Valero \& O. Skovsmose (Eds)., Proceedings of the $3^{\text {rd }}$ International MES Conference (pp. 1-10). Centre for Research in Learning Mathematics.

Turner, C., Adame, D. \& Nadworny, E. (2020, April 11). "There's a huge disparity": What teaching looks like during coronavirus. NPR. https://www.npr.org/2020/04/11/830856140/teaching-without-schools-grief-thena-free-for-all

Widman, J. (2020, December 2). What is Reddit? Digital Trends. https://www.digitaltrends.com/web/what-is-reddit/

Willis, J. (2012, June 13). Bad for the brain: Goodbye to unsustainable education models. Edutopia. https://www.edutopia.org/blog/bad-for-brain-unsustainable-modelsjudy-willis-md 


\section{Author Biography}

Sandra Schamroth Abrams, Ph.D., is Professor in the School of Education at St. John's University, New York. Abrams's investigations of digital literacies, videogaming, and technology integration explore layered meaning making and agentive learning. Abrams is author/editor of over 75 works, including 8 books and 6 special issues. Abrams serves on multiple editorial boards and is an Associate Editor for the International Journal of Multiple Research Approaches and a founding co-editor of the Gaming Ecologies and Pedagogies book series (Brill). Her ORCID is https://orcid.org/0000-0003-0535-9170 